УДК 821.І6І.І.0

ББК $83.3(2 \mathrm{Poc}=\mathrm{Pyc})$

\section{БУКЕТ ФИАЛОК И НЕМНОГО НЕРВНО: ШТРИХИ К НОБЕЛЕВСКИМ ДНЯМ 1933 Г.}

(C) 2020 г. Т.В. Марченко

Институт мировой литературы

им. А.М. Горького Российской академии наук, Москва, Россия; Дом русского зарубежья им. А. Солженицына, Москва, Россия Дата поступления статьи: 25 декабря 2019 г. Дата публикации: 25 декабря 2020 г.

DOI: https://doi.org/IO.22455/2500-4247-2020-5-4-472-505

Статья по гранту РФФИ: 20-ог2-оо539 А «Нобелевские лауреаты Б.Л. Пастернак (1958) и М.А. Шолохов (1965) в европейской кросс-культурной коммуникации. Новые материалы к истории русской литературы 1930-г96о-х г2.»

Аннотация: В 933 г. И.А. Бунин стал первым русским лауреатом Нобелевской премии по литературе. В основу статьи легли материалы, хранящиеся в московских архивах и дополняющие бунинскую нобелиаду, довольно полно воссозданную исследователями на основе зарубежных архивов и периодики. Эго-документы прямых участников и наблюдателей событий, развернувшихся между 9 ноября (известие о выборе Шведской академии) и 3 декабря (отъезд Бунина из Парижа в Стокгольм), сохранили подлинность исторического момента в трогательных деталях и отразили маневры различных идейно-политических сил, пытающихся манипулировать лауреатом. В бунинском фонде РГАЛИ отложились телеграммы лауреату, адресованные ему письма Е.П. Ковалевского и А.В. Карташева, вовлеченных в организацию парижских чествований, а также послания стокгольмских корреспондентов писателя. С этими материалами перекликаются дневниковые записи П.Е. Ковалевского и письма Карташева И.С. Шмелеву, хранящиеся в архивном фонде ДРЗ, и всю картину дополняют письма Г.Н. Кузнецовой Л.Ф Зурову из Стокгольма с припиской Бунина, хранящиеся там же. Все архивные материалы публикуются - полностью или в выдержках впервые.

Ключевые слова: русское зарубежье, Нобелевская премия по литературе, И.А. Бунин, газета «Возрождение», А.В. Карташев, И.С. Шмелев, П.Е. Ковалевский, эгодокументы, архивы.

Информация об авторе: Татьяна Вячеславовна Марченко - доктор филологических наук, ведущий научный сотрудник, Институт мировой литературы им. А.М. Горького Российской академии наук, ул. Поварская, д. 25 а, І2IO69 г. Москва, Россия; зав. отделом, ГБУК г. Москвы Дом русского зарубежья им. А. Солженицына, ул. Нижняя Радищевская, д. 2, Іо9240 г. Москва, Россия. ORCID ID: https://orcid.org/o000-0002-975I-03I9

E-mail: tvmarch@mail.ru

Для цитирования: Марченко Т.В. Букет фиалок и немного нервно: штрихи к нобелевским дням І933 г. // Studia Litterarum. 2020. Т. 5, № 4. С. 472-505. https://doi.org/I0.22455/2500-4247-2020-5-4-472-505 


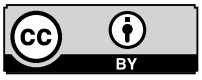

This is an open access article distributed under the Creative Commons Attribution 4.0 International (CC BY 4.0)

\title{
BOUQUET OF VIOLETS, OR BEING A BIT NERVOUS: FINISHING TOUCHES TO THE 1933 NOBEL DAYS
}

\author{
(C) 2020. T.V. Marchenko \\ A.M. Gorky Institute of World Literature \\ of the Russian Academy of Sciences, Moscow, Russia; \\ A. Solzhenitsyn House of Russia Abroad, Moscow, \\ Russia \\ Received: December 25, 2019 \\ Date of publication: December 25, 2020
}

Acknowledgements: This research has been supported by the Russian Foundation for Basic Research (RFBR), no 20-0I2-00539

Abstract: In I933, Ivan Bunin was the first Russian author to be awarded the Nobel Prize in literature. This article bears on the materials held in Moscow archives that contribute to the Bunin "Nobeliade" that researchers have reconstructed relying on foreign collections. The ego-documents of direct participants and first-hand witnesses of the events that took place between November 9 (the announcement of the Swedish Academy) and December 3 (Bunin's departure from Paris to Stockholm) add touching details to this historical moment and also demonstrate different attempts to manipulate the laureate. Dozens of telegrams and some letters to the laureate are stored in the Russian archive of art and literature. They overlap with the letters of the abovementioned Bunin's correspondents to other persons held in the House of Russia Abroad. They latter archive also includes a handwritten note of Bunin. This is the first publication of the mentioned archive materials.

Keywords: Russian émigré, Nobel Prize for literature, Ivan Bunin, newspaper Vozrozhdenije (Renaissance), A.V. Kartashev, I.S. Shmelev, P.E. Kovalevskij, ego-documents, archives.

Information about the author: Tatiana V. Marchenko, DSc in Philology, Leading Research Fellow, A.M. Gorky Institute of World Literature of the Russian Academy of Sciences, Povarskaya 25 a, I21069 Moscow, Russia; Head of the Department, A. Solzhenitsyn House of Russia Abroad, Nizhnyaya Radishchevskaya 2, I09240 Moscow, Russia. ORCID ID: https://orcid.org/oooo-0002-975I-03I9

E-mail: tvmarch@mail.ru

For citation: Marchenko T.V. Bouquet of Violets, or Being a Bit Nervous: Finishing touches to the 1933 Nobel Days. Studia Litterarum, 2020, vol. 5, no 4, pp. 472-505. (In Russ.) https://doi.org/Io.22455/2500-4247-2020-5-4-472-505 
К г5о-летию И.А. Бунина

\section{Нобелпремия}

В первой книге ІІо-го тома «Литературного наследства» [3], спустя почти полвека [2] вновь посвященного И.А. Бунину накануне его г5о-летнего юбилея, опубликованы на цветных вклейках фотографии диплома и медали первого русского лауреата Нобелевской премии по литературе (I933), хранящихся в Русском архиве Особых коллекций Бротертонской библиотеки Лидского университета (Великобритания).

Обратившись к истории присуждения самой известной международной награды русским писателям (см.: [7; 8; 9; Іг; г2]), мы рассматривали нобелиаду Ивана Бунина на материалах архива Шведской академии (Стокгольм), с привлечением русской эмигрантской, французской и шведской периодики, а также других, прежде всего зарубежных, архивов. За последнее время «нобелевский сюжет» биографии И.А. Бунина пополнился новыми материалами, главным образом из личного архива писателя и его окружения в Лидсе [5; 3, с. 664-690]. Удивительным образом исследователи (включая автора этих строк) упустили из виду некоторые весьма любопытные документальные свидетельства тех «невозможных» дней радостно-праздничных и мучительно-утомительных и для лауреата, и для его близких. Среди тех, чьи послания Бунину или записи о нем мы впервые приводим ниже, были и именитые обитатели русского Парижа, непосред-

I «[Р]ассказать, как я живу эти дни, невозможно», - уверял близких Бунин [3, с. 668], письмо от Iо.II.I933. По крайней мере ноябрь и декабрь I933 г. прошли для лауреата и его окружения в круговерти изнурительной праздничной горячки. 
ственно принимавшие участие в организации торжеств в честь писателя и в самих торжествах, и жители Стокгольма, причастные к приему русского лауреата в шведской столице, и те, кому выпала роль наблюдателей, способных трезво оценить события - и со сцены, и с галерки, неизбежно зоркой и критичной. Публикуемые ниже эго-документы и выдержки из них ${ }^{2}-$ это не детальное восстановление парижских чествований в ноябре г933 г. первого русского нобелевского лауреата по литературе, а лишь некоторые прежде упущенные детали из бунинской нобелиады - одного из самых ярких эпизодов в истории русского межвоенного Парижа.

Как только 9 ноября в Стокгольме был объявлен нобелевский лауреат по литературе г933 г., на Бунина обрушился шквал поздравлений, о чем наглядное представление можно получить, листая каталог лидской архивной коллекции писателя [I7], где в датах бессчетно повторяется цифра г933 и даже создана особая единица хранения - список «Нобелевские дни» (MS.Io66/I377) с перечислением организаций и лиц, откликнувшихся на одно из самых значительных событий в жизни межвоенного русского зарубежья - присуждение Нобелевской премии русскому писателю-эмигранту³. Несколько десятков телеграмм, адресованных на виллу Бельведер в Грассе, сохранились в бунинском фонде РГАЛИ на ленте микрофильма, ощущаешь ту сумасшедшую радость, которая охватила русский литературный Париж, все русское рассеяние. Телеграммы, разложенные в алфавитном порядке5 (Аминадо, Бахрах, Блох, Городецкая, Даманская, Демидов, Зайцевы Соллогубы, Кнут, Ландау (Алданов), Лазаревский, Оцуп, Сазонова, Тэффи, Фельзен, Ходасевич, Цетлин, Юшкевич), основным потоком пришли 9-II ноября г933 г., но не иссякали всю неделю, даже весь месяц.

\footnotetext{
2 Все архивные документы цитируются по современной орфографии и пунктуации, включая имена собственные, с исправлением по умолчанию орфографических ошибок и описок, с расставлением принятых в современном правописании знаков препинания; все личные обороты речи сохранены. Все переводы с иностранных языков принадлежат нам T.M. Все подчеркивания принадлежат цитируемым авторам. Известные лица, события, факты не комментируются.

3 Многие из поздравлений, сохранившихся в лидской части бунинского архива, мы цитируем в: [8, с. $405-433]$.

4 РГАЛИ. Ф. 44. Оп. 2. Ед. хр. г37. 53 л.

5 Возможно, Буниными при разборке архива, поскольку кое-где оставлены рукописные пометы, например: «Лоло, Вера Мунштейн» (фамилия вписана), а на двух бланках, возле имен Кулишера и Фельзена, приписано: «погиб у немцев».
} 
Текст телеграммы, несмотря на его лаконичность и известную однотипность, вызванную острым желанием немедленно поделиться с виновником торжества восторгом от невероятной и прекрасной новости и поздравить его, все же дает порой представление о личности автора послания и о его отношении к адресату. Телеграммы отражают самую первую, спонтанную реакцию и позволяют ощутить атмосферу пьянящего счастья, охватившего в те дни всю эмиграцию. За единичным исключением, телеграммы были отбиты по-французски, иногда с вкраплением русских слов или фраз латиницей. «Горячо», и «сердечно» - самые расхожие эпитеты: «Сердечные поздравления. Д. Мережковский, 3. Гиппиус», «Поздравляем от всего сердца. Одоевцева, Георгий Иванов». Для кого-то Нобелевская премия Бунина - личная радость, другие счастливы за лауреата, но есть и те, кто торжествует от имени всей русской литературы и от всей эмиграции: «Счастлива за вас, за русское дело, горячо поздравляю. Сазонова», «Братски поздравляю лауреата, да здравствует наша великая русская литература. Шмелев», «ваш праздник - это общий праздник. Кнут».

Бунина именуют «нашим великим писателем» (В. и О. Барятинские, Бикерманн, Кулишер), «славой русской литературы» (Тэффи). Упрямая М.И. Цветаева, не разделяя всеобщего преклонения перед Буниным, но горячо радуясь за русскую литературу, отбила из Кламара го ноября телеграмму жене лауреата, Вере Буниной: «Первая Нобелевская премия <по литературе>. Благородство. Женская твердость. Марина». После ее имени от руки вписано латиницей: Zwietaeva. «Пятнадцать Струве» (так и подписано) телеграфировали из Парижа, а Глеб Струве особо - из Лондона. На имя Н.К. Кульмана пришла телеграмма от актера и режиссера Александра Санина (и была передана адресату - нобелевскому лауреату). Бланк проштемпелеван, но телеграмма эта, в отличие от всех прочих, написана от руки невообразимыми каракулями, причем это одновременно и транслитерация, и транскрипция на латинице русского текста, который, впрочем, можно разобрать: «Приветствую, радуюсь мировому признанию Вашего таланта, которым родина гордится издавна». А.П. Буров и Сергей Горный (А.А. Оцуп), телеграфирующие из Берлина, экономно воспользовались немецким словообразованием и поздравили Бунина с «Нобелпремией» (Nobelpreis). Сохранившиеся без штемпеля две телеграммы были адресованы «Mme Bounine» - от семьи Алексинских («Обнимаем лауреата 
и вас») и от Г.В. Адамовича из Ниццы («Искренние поздравления, всем тысяча пожеланий»). Вероятно, самая замечательная количеством и «качеством» подписей телеграмма была послана I3 ноября: «Ежемесячное собрание “Кочевья” шлет вам искренние поздравления. Слоним, Ладинский, Браславский, Берлин, Соколовский, Шеметов, Берберова, Адамович, Смоленский, Болотов, Червинская, Кнут, Кильберин, Дикой, Алферов, Риви, Мандельштам, Островский, Кривицкий, Гершуни, Лапина, Гринберг, Постников, Фельзен, Герцык, Раевский, Зульцер, Кауфман, Луцкий, Горлин, Терапиано, Варшавский, Блох, Ставров, Прегель». Комментировать этот список нет нужды.

Отозвалось и несколько переводчиков: Рут Ведин-Ротштейн (Rothstein) из Стокгольма, Кэте Рохзенберг и <A.3.> Штейнберг (Steinberg) ${ }^{6}$ из Берлина, французы - Монго (Mongault), Дени Рош (Roch), Анна Жинест-Тези (Gineste-Tesi). Последняя лучше всех выразила общее чувство: «Всем сердцем присоединяемся к тем, кто празднует в вашем лице триум русской мысли». Среди откликнувшихся «celebrities» оказался нобелевский лауреат I930 г. Синклер Льюис, телеграфировавший I4 ноября из Чикаго (некогда Томас Манн с напускной забывчивостью назвал знаменитый рассказ Бунина «Человеком из Чикаго»). Этот краткий текст заслуживает того, чтобы привести его в оригинале:

To the gentleman from Russia who made the gentleman from San Francisco so gloriously living my most affectionate congratulations on the Nobel Prize. Sinclair Lewis.

Господину из России, создавшего и прославившего господина из Сан-Франциско, мои самые душевные поздравления с Нобелевской премией. Синклер Льюис.

27 ноября лаконично телеграфировала Сельма Лагерлёф - нобелевский лауреат 1909 г., член Шведской академии (с I9I4 г.): «Благодарности, поздравления».

6 Подпись без инициалов; всего вероятнее, А.З. Штейнберг (г89I-1975) - философ, публицист, переводчик, автор работ о Достоевском, активный участник литературно-культурной жизни русского Берлина (1923-1934). 


\section{Букет фиалок}

Общее эмигрантское воодушевление и собственное обоснование справедливости увенчания именно Ивана Бунина филолог и историк Петр Евграфович Ковалевский7 доверил дневнику. Одна из копий этого дневника хранится в Доме русского зарубежья им. А. Солженицына в фонде Ковалевских в виде собственноручной машинописи с правкой․ П.Е. Ковалевский довольно подробно протоколировал эмигрантскую повседневность, заносил в дневник и значительные, и мелкие события из церковно-религиозной жизни русской диаспоры, а также факты безусловного историко-культурного значения9. К таким и относится запись от го ноября (28 октября; все записи датированы двумя стилями) г933 г. Это была пятница:

С величайшей радостью узнали сегодня из газет о присуждении Ивану Алексеевичу Бунину Нобелевской премии по литературе. Для него это и почетно, и дает возможность жить и издавать, а для всех русских - большая победа, так как в первый раз премия выпадает на их долю, да еще в такие безнадежные времена. Самое отрадное, что венец выпадает последнему русскому классику и писателю Пушкинской школы, а не современному «стилисту». Он последний русский академик по разряду изящной словесности. Уже сегодня, верно, со всех концов русского рассеяния полетели приветствия и радостные пожелания ${ }^{\mathrm{I}}$.

7 П.Е. Ковалевский (I90I-I978) - доктор историко-филологических наук (диссертация на тему «Н.С. Лесков (биография, критика трудов, библиография)» защищена в Сорбонне 30 января 1926 г.), преподаватель Свято-Сергиевского Богословского института, религиозный мыслитель и автор первого энциклопедического обзора о русской эмиграции (197I) «Зарубежная Россия: История и культурно-просветительская работа русского зарубежья за полвека (1920-І970)». Сын Евграфа Петровича Ковалевского (I865-194I), политического и общественного деятеля, председателя отдела средней школы Русской академической группы в Париже, одного из руководителей комитета по обеспечению высшего образования русскому юношеству за границей.

8 Более подробно о фонде и legenda к нему, а также о дневнике П.Е. Ковалевского см.: [6]. 9 Публикуя дневник П.Е. Ковалевского за г924 г., Н.В. Ликвинцева отмечает, что «с ранней юности и до глубокой старости он старается каждый день вести дневник и фиксировать в нем историческую канву собственной жизни, акцентируя внимание не столько на личной истории, сколько на приметах времени и эпохи» [6, с. 85].

Іо ДРЗ. Ф. 69. Семейный фонд Ковалевских. Оп. г. Дневники П.Е. Ковалевского І9І8-І938 гг. Ед. хр. 45. І933 г. август-ноябрь. Л. 72. 
Коллективное поздравление почетному академику ${ }^{\text {II }}$ от Русской академической группы подписали А.Н. Анциферов, Н.А. ДобровольскаяЗавадская, С.Е. Савич и отец автора процитированного дневника Е.П. Ковалевский ${ }^{\text {I2 }}$ Евграф Петрович вступил от имени группы в переписку со свежеиспеченным нобелевским лауреатом по поводу организации его чествований в Париже. В понедельник г3 ноября г933 г. из редакции газеты «Возрождение» (в левом верхнем углу указаны лишь день недели и место, где письмо создавалось, возможно, коллективными усилиями) Евграф Петрович пишет ${ }^{13}$ :

\section{Глубокоуважаемый и дорогой Иван Алексеевич!}

Кроме банкета Современных записок ваши «читатели и почитатели» хотели бы устроить Вам «встречу и здравицу» от рядовых эмигрантов, для которых назначение Вам Нобелевской премии ${ }^{\mathrm{I4}}$ было огромной радостью! ${ }^{\text {б) }}$

Предполагается в субботу ${ }^{15}$ в 4 часа дня собраться на quai de Tokyo ${ }^{\mathrm{I}}$. Вступительное слово Маклакова В.А. как председателя дня русской культуры,

II И.А. Бунин был избран почетным академиком по разряду изящной словесности в Санкт-Петербургскую Императорскую академию наук в г909 г. «[Д]еятели литературы и искусства высоко ценили избрание их почетными академиками, рассматривали его не только как проявление внимания Академии наук к отечественной культуре, но и как акт общероссийского признания» [13].

I2 РАЛ. MS.Іо66/І637-І638. Еще одно имя осталось нерасшифрованным составителем каталога Э. Хэйвудом и оставлено под вопросительным знаком: [Brovskii?] [ı6, с. 6о]. Всего вероятнее предположить, что неразобранной оказалась подпись профессора-экономиста М.В. Бернацкого, упоминаемого далее в разных контекстах бунинских торжеств.

І3 РГАЛИ. Ф. 44. Оп. 2. Ед. хр. пІ9. Л. г.

I4 Подчеркнуто автором письма; слова «назначение Вам Нобелевской» подчеркнуты дважды.

I5 Чествование Бунина состоялось в воскресенье 26 ноября в Театре Елисейских полей. Помимо названных Ковалевским русских участников (Маклаков, Зайцев), на вечере выступили: профессор русского языка и литературы филологического факультета Сорбонны, автор ряда книг о России Эмиль Оман (Haumant; 1959-1942) и члены Французской академии, лауреаты Гонкуровской премии братья Жером (І874-1953) и Жан (I877-1952) Таро (Tharaud) (подробнее см.: [го, с. 528]). «Последние новости» и «Возрождение» дали об этом чествовании краткие отчеты 27 ноября и развернутые -28 ноября.

I6 26, av. de Tokyo (I6 округ) - по этому адресу собиралась на заседания Русская академическая группа (членами которой, в частности, были двое из цитируемых в настоящей статье авторов - А.В. Карташев и Е.П. Ковалевский, а также главный редактор газеты «Возрождение» Ю.М. Семенов). В одном из двух крыльев в здании Дворца Токио, возведенного в I937 г. к Всемирной выставке, размещалась Русская Консерватория (Консерватория Русского народного университета им. С.В. Рахманинова). Дворец получил свое название по улице, на которой находился, - авеню Токио (до г935 г., сейчас носит название авеню Нью-Йорка). 
краткая речь Б.К. Зайцева как литератора и мое приветствие от читателей и почитателей в заключение.

го-летняя Таня Тимашова ${ }^{17}$ поднесет Вам букет фиалок и квартет Кедрова ${ }^{18}$ пропоет славу. Вы скажете в ответ то, что пожелаете. Затем будет подано вино и печенья - чокнутся, поздравят, Вы пожмете несколько десятков

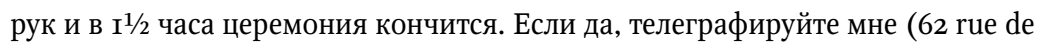
Republique Meudon S.O. ${ }^{19}$ ). В состав инициативной группы входят от Академической группы <А.Н.> Анциферов - проф. <M.В.> Бернацкий $-<$ А.В.> Карташев - Ю. $<$ Ф. $>$ Семенов и др. -

Примите горячие и искренние поздравления от меня и моей семьи.

Душевно к вам расположенный Е. Ковалевск<ий>

(Евграф Петрович)

х) Для них банкет может стать подарком.

Это письмо еще не успело прийти в Грасс, как вдогонку полетела следующая записка, набросанная Е.П. Ковалевским I4 ноября на бланке Русской академической группы (Groupe académique russe) ${ }^{20}$ и озаглавленная, несмотря на краткость, «О чествовании в Париже»:

Идея Вашего чествования разрастается, скромный проект вчерашнего дня оставлен. В.А. Маклаков собирается созвать представителей общественных организаций и по согласованию с Вами обсудить, где и как устраивать это чествование.

Поскольку проспект проложен по набережной, то очевидна обычная ошибка в адресе - quai (набережная) вместо avenue (проспект).

I7 Татьяна (Таня, Тата) Тимашова - ученица балетной студии О.И. Преображенской, балерина.

I8 Мужской квартет Н.Н. Кедрова (I87I-I940). Созданный в России в начале XX в., когда сам Николай Николаевич Кедров, происходивший из духовного сословия, был оперным певцом, выступал на сцене Мариинского театра, квартет исполнял вокальную музыку самых разных жанров. В эмиграции воссозданный квартет дал свой первый концерт в 1923 г. в Берлине; Н.Н. Кедров выступал и в ипостаси композитора, сочиняя для квартета духовную музыку.

I9 Медон, улица Республики, 62. S.O. (фр. Seine-et-Oise) - департамент Сены и Уазы с центром в Версале, создан в І790 г., упразднен в 1968 г.

20 РГАЛИ. Ф. 44. ОП. 2. Ед. хр. ІІ9. Л. 2. 
Однако именно в этот день, I4 ноября І933 г., И.А. Бунин сам отправился в Париж - в ореоле нобелевского лауреата, и все дальнейшие переговоры и обсуждения велись устно. Письма и телеграммы направлялись уже не в Грасс на виллу Бельведер, а в отель «Мажестик», где поселился «При-Нобель».

\section{Теплое слово}

В день присуждения премии Бунину телеграфировали из Стокгольма самые разные лица - журналисты И.М. Троцкий и, «без ума от радости», С. Шессен (С.Б. Шерешевский) ${ }^{21}$, Нильс Гебер, рядом с именем которого сохранилась приписка рукой Бунина: «шведский издатель» ${ }^{22}$.

I6 ноября Нильс Гебер и Серж Шессен (С.Б. Шерешевский) телеграфируют на Бельведер вместе, и смысл телеграммы:

Не стесняйтесь воспользоваться гостеприимством Олейникова. В любом случае будет тише. Горячо надеемся на приезд г-жи Буниной²3,

- мог бы озадачить, если бы не письмо самой Веры Николаевны мужу в Париж, в котором она подробно рассказывает, как они с «Галей» (Г.Н. Кузнецовой) готовятся к поездке в Швецию, и пытается выяснить, действительно ли Иван Алексеевич задумал ехать туда один [3, с. 666-667]. Фразу В.Н. Буниной в письме к мужу от 2I ноября: «Гебер в телеграмме меня приглашает в Стокгольм» - публикаторы откомментировали следующим образом: «Телеграмма неизвестна» [г, с. 669-670]. Можно было бы счесть, что это процитированная выше телеграмма, которую Вера Николаевна получила в отсутствие отправившегося в Париж мужа, вероятно, это еще одна телеграмма, о которой речь пойдет ниже. Отметим только, что гостеприимством Нобелей-Олейниковых Бунин воспользовался 24 , хотя надежды на ти-

2 І РГАЛИ. Ф. 44. ОП. 2. Ед. хр. г22. Л. І.

22 РГАЛИ. Ф. 44. ОП. 2. Ед. хр. ІІ5. Л. І. Поскольку шведы телеграфировали по-французски, то имя шведского издателя в архивной описи оказалось переданным по-русски в соответствии с французским произношением: Жебер.

23 РГАЛИ. Ф. 44. ОП. 2. Ед. хр. ІІ5. Л. 3.

24 Вместе с Эммануилом Нобелем чета Олейниковых с г923 г. снимала большую квартиру в доме по адресу Södra Blasieholmskajen 4A, на набережной напротив Королевского дворца и прямо по соседству с Гранд-отелем, где традиционно останавливались нобелевские лауреаты. В г932 г. Э. Нобеля не стало, его трехкомнатные апартаменты освободились; именно в 
шину не оправдались; Г.Н. Кузнецова писала Л.Ф. Зурову из Стокгольма го декабря, что живут они с Верой Николаевной в одной комнате и «довольно бесприютны, т. к. во всех комнатах целый день толчется народ» 25.

Дважды Вера Николаевна сообщает мужу о необычайно для нее лестном предложении шведского издателя: «Да, главное: Гебер просит ему дать право на шведском языке издать мои мемуары! Прислал телеграмму» (письмо от г6 ноября [3, с. 665]); «Гебер просит телеграммой авторизацию у меня на мои мемуары. Я ответила ему на превосходном французском языке ни да, ни нет. Но меня это очень подбодрило. Может быть, и на моей улице будет праздник, и я заработаю кроны. Ведь у меня много написано» (письмо от I8 ноября [3, с. 667]). Вера Николаевна, очевидно, сильно воодушевилась, да и хотелось блеснуть собственными успехами перед прославленным на весь мир «Яном». Коллектив публикаторов переписки полагает, что и такая «телеграмма неизвестна» [3, с. 665], «телеграмма Н. Гебера не сохранилась» [3, с. 668]. Однако не сохранилась она в лидской коллекции Буниных, поскольку попала в фонд писателя в РГАЛИ, дело так и озаглавлено: «Телеграмма Жебера (Geber) Буниной-Муромцевой Вере Николаевне» ${ }^{26}$. Телеграмма, где речь идет и о мемуарах, и о приглашении в Стокгольм, была отбита также г6 ноября, вот ее текст:

Если вы пишете мемуары, сохраните, пожалуйста, права на шведское издание за мной. Добро пожаловать вместе с мужем в Стокгольм, с наилучшими чувствами, Гебер.

Это издание, к сожалению, не состоялось.

Пространная телеграмма Н. Гебера от 24 ноября носит чрезвычайно деловой характер, связанный с правами на перевод и издание в Швеции бунинских произведений. Это послание в го строк, впрочем, объясняется лишь обычной ежегодной шумихой вокруг нового нобелевского лауреата и коммерческими - в отношении Бунина совершенно не оправдавшимися -

них и остановился И.А. Бунин в декабре г933 г. Сейчас это здание принадлежит Шведскому автомобильному клубу. За предоставленную информацию благодарим писателя, переводчика Бенгта Янгфельдта (Jangfeldt; Швеция).

25 ДРЗ. Ф. 3. Зуров Леонид Федорович. Оп. г. Ед. хр. 50. Л. 30.

26 РГАЛИ. Ф. 4. Оп. 2. Ед. хр. І73. Л. І (с характерной ошибкой в транскрипции шведского имени по французскому образцу). 
расчетами издателей. Завершается телеграмма с оптимизмом: «Ждем вас в Стокгольме для решения о новых изданиях» ${ }^{27}$.

Еще одно послание, переданное телеграфом из Стокгольма, имеет эпистолярную предысторию. Профессор А.В. Карташев, учеником которого был П.Е. Ковалевский - и в Свято-Сергиевском богословском институте, и на историко-филологическом факультете русского отделения Парижского университета, - принимал самое активное участие в торжествах, устроенных во французской столице в честь Бунина. Однако сам факт, что он пишет письмо, а не пытается переговорить с нобелевским лауреатом лично, как нельзя лучше раскрывает фантасмагорическую атмосферу тех дней. Тема письма, между тем, прямо касается поездки в Стокгольм, а тон Антона Владимировича, который моложе Ивана Алексеевича пятью годами (г875-1960), несколько брюзглив. За неделю в роскошном номере «Мажестика» Бунин далеко продвинулся в столь упоительной для него роли гордости и славы русской литературы ${ }^{28}$. Дата и подпись составляют единое целое с этим посланием.

22.XI.I933

Дорогой Иван Алексеевич.

Удосужьтесь до Стокгольма $^{29}$ прочесть эти мои строки. Не могу удержаться не высказать Вам мой совет.

В первых рядах русской колонии там Вы встретите священника Александра Рубцаз ${ }^{30}$ Он, собственно, заместитель штатного протоиерея о. Петра

27 РГАЛИ. Ф. 44. Оп. 2. Ед. хр. ІІ5. Л. 2. В издательском доме Нильса Гебера в переводе на шведский язык вышли (тираж несколько раз допечатывался) три книги Бунина - «Юность Арсеньева»; «Странствия Арсеньева»; «Деревня. Суходол»: Arsenjevs ungdom / av Ivan Bunin / bemynd. övers. från ryska originalet av Ruth Wedin Rothstein. Stockholm: Geber, I93I. 288 s.; Arsenjevs irrfärder / bemynd. övers. från ryska originalet av Ruth Wedin Rothstein. Stockholm: Geber, I933. I53 s.; Byn. Suchodol / bemynd. övers. från ryska originalet av Ruth Wedin Rothstein. Geber, I933. 289 s. Ряд книг выпустили (до г933 г. включительно) другие издательства [8, с. 3І4-326]. После присуждения Бунину Нобелевской премии ни одной книги Бунина в Швеции издано не было, вплоть до недавнего перевода «Темных аллей»: Bunin Ivan. Mörka alléer / översättning av Per-Olof Andersson. Örebro: Akvilon, 2008. I96 s.

28 Впрочем, и богослов склонен к морализаторству даже в кругах ему гораздо более близких, например, в письмах к И.С. Шмелеву не отказывает себе порой в «нравоучении, которое учитель прописывает своему нерадивому ученику» [I5, с. I84].

29 Первые три слова подчеркнуты дважды.

30 Рубец (Roubetz, Rubetz, Roubets) Александр Александрович (I882-I956) - активный член русской колонии в Швеции, в Стокгольме с г9I8 г. Доктор юриспруденции, препо- 
Румянцева. Старик Румянцев уже полная руина. Но живет при той же русской посольской церкви, которая осталась единственным центром нац<иональ-

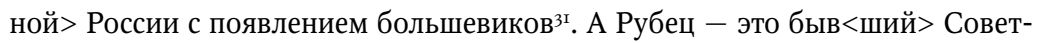
ник нашего посольства в Норвегии, лицеист, дипломат, ч<елове>к светский. Он преподает русск<ую> историю и литературу в средней школе и читает лекции в шведск<ом> университете. Языки знает в совершенстве. Ч<елове>к бойкий, тароватый, благодушный семьянин, - единственная борода (в виде ласточкина хвоста) во всей Швеции - на удивление всем студентам и мальчишкам. Дети думают, что это рождественский дед.

Для большинства русской колонии (не еврейской и мало-мальски верующей), наши иереи там - некий возглавляющий символ русской культуры. И буржуазное протестантское шведское общество так же смотрит на них. И вам надо не упустить это из внимания. Вероятно, и Серг <ей $>$ Серг <еевич $>32$ Шершевский вам их надлежаще представит и покажет. Если будут приглашать - загляните к ним ${ }^{33}$, поклонитесь тени России в маленькой церкви, в солидном краснокирпичном доме уютно устроенной. Иначе, пожалуй, русские огорчатся, и шведы не поймут.

Берегите нервы и здоровье.

Сердечно Ваш

А. Карташев.

Не иначе как благоприятный ответ от Бунина был получен, и Карташев нашел случай дать об этом знать в Стокгольм, потому что Александр

даватель в ряде учебных заведений в Стокгольме и в Упсале, автор ряда работ по русской литературе и русской православной церкви. Священник, рукоположен в сан в 1929 г. Основатель православного прихода в Осло (1931), служил в нем с 1935/1936 по г947 г. В г950-е гг. был настоятелем домовой Свято-Иннокентиевской церкви в шведском городе Эскильстуна (Eskilstuna). Близкие Бунина не запомнили его имени и называли в письмах и публикациях другими инициалами (Н., М. и под.)

3I Свято-Преображенская церковь - православный приход Константинопольского патриархата - расположена по адресу Birger Jarlsgatan, 98. Протоиерей Петр Румянцев (I854-1935) стал настоятелем в I888 г., при нем было возведено и им освящено новое здание церкви. О. Петра Румянцева, члена ряда научных обществ и автора очерка «Из истории русской православной церкви в Стокгольме» (Берлин, г9го), в І936 г. сменил священник Стефан Тимченко, выпускник Свято-Сергиевского богословского института в Париже.

32 Правильно: Борисович.

33 Подчеркнуто так. 
Рубец, так душевно аттестованный и горячо рекомендованный русскому писателю, отправил ему из Стокгольма письмо, датированное г2/25 ноября I933 г. ${ }^{34}$ В левом верхнем углу традиционно приведен адрес (в отдаленном восточном пригороде «Ольстен» (Älsten; правильно Эльстен) и должности автора письма, по-русски - священник, и по-шведски - пастор (священник), преподаватель университета.

Простите, что, не будучи Вам известен, решаюсь писать Вам и тем отнимаю от Вас время, но делаю это с благословения С.Б. Шершевского, с которым я в хороших отношениях и который посоветовал мне обратиться прямо к Вам. Позвольте сказать Вам, что я, кроме того, что я священник нештатный, для Швеции и Норвегии, состою лектором русского языка и литературы в Упсальском университете, в Высш[ей] коммерч[еской] академии в Стокгольме и в Правительственной гимназии в Стокгольме.

Дело в том, что я начал собирать русских людей на беседы по религиозно-нравственным вопросам, и будущая беседа состоится в пятницу 8 декабря в 8 ч<асов > вечера. Русские люди в Стокг<ольме> (их около І75 ч<еловек>) не имеют здесь пока никаких организаций, и потому единственный раз, когда они могли бы встретить Вас и услышать от Вас несколько слов, теплых слов дорогого для всех нас Русского Писателя, признанного теперь всем миром, это было бы на нашей беседе 8 декабря. Поэтому, если сможете, оставьте этот вечер для тех русских, которые не попадут на Ваше торжество и которые не смогут принять участие в другом чествовании Вашем.

Простите мою дерзость и, если можно, не откажите, помня, что здесь нас очень мало и мы очень разрознены пока. Соедините нас теплым словом, и Вы сделаете большое дело для нас, заброшенных здесь на Севере.

С чувством глубочайшего к Вам уважения

имею честь быть Вашим покорным слугою

и богомольцем

священник Александр Рубец.

Спустя несколько дней после того, как это чудесное, доброе и светлое письмо было получено в Париже, где прославленный на весь мир великий 
писатель русский едва ли помышлял о вопросах религиозно-нравственных, программа нобелевских чествований в Стокгольме окончательно прояснилась, и о. Александр Рубец телеграфировал лауреату зо ноября в отель «Мажестик»35:

Русские в Стокгольме просят Вас пожаловать на чаепитие в Вашу честь 9 декабря в четыре часа или назначьте сами, когда Вам удобно. Умоляем ответить. Священник Рубец.

Отчет об этом чаепитии находим как в шведских газетах [8, c. 475-476], так и, в частности, в письме Г.Н. Кузнецовой Л.Ф. Зурову от Iо.I2.I933 $3^{36}$ : «Вчера были на чае, устроенном рус $<$ ской $>$ колонией в ресторане, стоящем в лесу среди зоол<огического > сада (проезжали мимо дворца Марьи Павловны). Русских здесь мало, очень ошведились, говорят с трудом. И<вану $>$ А<лексеевичу> вдели в петлицу трехцветный значок, пели ему и $\mathrm{B}<$ ере $>\mathrm{H}<$ иколаевне > “Многая лета” <...>. Священник о. Н. <так!> Рубец сказал речь, очень театральную и декламаторскую, кот<орая>, кажется, однако всем понравилась, затем было предложено основать первое здесь лит<ературное> общество имени Бунина». Благие пожелания!37

35 Там же. Л. 2.

36 ДРЗ. Ф. 69. ОП. г. Ед. хр. 46. Л. 29. Упомянутые ниже локации находятся на Юргордене - островном парке, где был, в частности, выстроен дворец (собственно, вилла) Марии Павловны, внучки Александра II, в I908 г. ставшей женой герцога Зюдерманландского Вильгельма, сына шведского короля Густава V. Ресторан, находившийся в глубине Юргордена в Скансене, в старинном деревянном доме, носил название «Чердак» (Högloftet).

37 Об инициативе создать «Русско-шведское общество друзей русской культуры им. И.А. Бунина» см.: [4]. В феврале г934 г. в актовом зале Института коммерции (Handelsehögskola) прошло первое заседание. Временным председателем общества стал А. Рубец, поскольку от почетного председательства отказался граф Толстой (из опубликованных отрывков переписки не известно, был ли это Л.Л. Толстой или кто-либо из его старших сыновей - Павел или Никита). Затея с обществом довольно быстро провалилась; современная исследовательница жизни русской колонии в межвоенной Швеции полагает, что причиной стал главный инициатор создания общества Сергей Цион - «личность весьма спорная и доверия среди членов диаспоры не вызывавшая» [4, с. І65-г66]. За три года общество провело, судя по сохранившимся данным, один концерт из произведений русских композиторов и одно собрание; в 1937 г. оно было ликвидировано, а книги были сданы в церковную библиотеку [4, с. І66]. 


\section{Психологический предел}

Если бы русские в Стокгольме знали, какие нешуточные страсти бушуют вокруг нобелевского лауреата в русском Париже, какая разгорелась «партийная» борьба за первого нобелевского лауреата по литературе первого из русских писателей, первого апатрида... Буниным мгновенно начинают манипулировать, он уже не принадлежит ни себе, ни русской литературе, его внезапное и по эмигрантским меркам немыслимое богатство ослепляет, и на фоне букетов, банкетов, фраков, мехов, толчеи журналистов и вспышек фотокамер разговоры о миссии эмиграции кажутся вздором, хлеб-соль - нелепой бутафорией, а неразличимый хоровод незнакомых, продувных и веселых людей смыкается вокруг лауреата все теснее и кружит его в бешеном вихре. Совсем по Пушкину - словно листья в ноябре...

Православно-монархическое, национально ориентированное, очень серьезное и совсем неспособное договориться о единстве действий крыло эмиграции тонко улавливает, какой огромный идейно-духовный потенциал содержит в себе Нобелевская премия - воскрешения от обыденности, совместного душевного подъема, своего рода общекультурного очищения эмиграции, когда и мировое признание, и деньги, по праву присужденные одному, могут быть использованы во благо для многих, вложены в полезное начинание, для помощи и поддержки, в частности, всему писательскому сообществу. Но взяться за это никто не умел, и лауреат меньше всего, тысячи и десятки тысяч франков растрачивались попусту на никому не нужные пиры, были выкинуты на ветер, главные слова не были сказаны, дело не делалось. Дневники и письма сохранили грустные свидетельства того, как нобелевские чествования Ивана Бунина не стали общим праздником русского Парижа, принесли горечь и разочарование многим его почитателям.

Накануне торжеств в честь нобелевского лауреата, а затем отчитываясь о прошедшем вечере, А.В. Карташев пишет И.С. Шмелеву - писателю, гораздо ему более близкому по всему строю мыслей и чувств, и письма эти отражают партийную возню вокруг столь радостного и, казалось бы, объединяющего события. Нобелевская тема вплетается в подробное сообщение Карташева от 23 ноября, как идут его хлопоты по возобновлению сотрудничества Шмелева в газете «Возрождение». А.О. Гукасов, владелец газеты, отвечает «готовой выношенной формулой», «благословляя» сотрудников газеты обратиться к Шмелеву, но сам писать не может: «Самолюбие газеты 
не позволяет. “Возрождение” не может забыть, как его “заушали” тридцать с чем-то человек, уходивших за Струве. И вы отреклись от него “с треском”, как он выразился» ${ }^{8}$. Карташев приводит и весьма дельные коммерческие соображения Гукасова - будь нобелевский лауреат Бунин столь же чуток к конъюнктуре эмигрантского книжного рынка, история с изданием его собрания сочинений [І4] могла бы повернуться по-иному: «[Р]усская <эмигрантская> провинция требует от нас грубых детективных романов, а не тех литературных, что мы даем» [I4]. На с. 4 письма (л. 9) Карташев передает еще один момент из состоявшегося разговора:

Гукасов оч<ень $>$ просил меня пойти на честв $<$ ование $>$ Бунина в Елис<ейских> полях и сказать там «от “Возрождения” (?!), если ${ }^{39}$ Милюков вылезет от “Послед<них> новостей”. Программа чествований до сих пор для “Возрождений” <так!> тайна (!!!).

Я сказал, что свое слово приберег для особого чествования в “Росс $<$ ии $>$ и Слав <янстве>”, как мне сказал М.М. Федоров, - под Вашим председат $<$ ельст $>$ вом $^{40}$.

На конверте процитированного письма (штемпель 24.XI.I933) 2 карандашные пометы, разным почерком: «от Карташева» и «о честв<овании> Бунина». В письме от 25 (г2) ноября обсуждение грядущих торжеств сразу выступает на первый план ${ }^{4}$.

38 ДРЗ. Ф. 4І. Оп. 3. Ед. хр. 467. Л. 6. В І927 г. П.Б. Струве покинул пост главного редактора «Возрождения», из солидарности с ним в газете перестал печататься целый ряд авторов, включая И.А. Бунина, опубликовавшего на страницах газеты публицистический цикл «Окаянные дни».

39 Подчеркнуто дважды.

40 Федоров Михаил Михайлович (1958-1949) - окончил физико-математический факультет Санкт-Петербургского университета; до революции - чиновник, экономист и предприниматель, общественный деятель, член партии кадетов. Примкнул к Белому движению, в эмиграции с 1920 г., жил в Париже. Активно участвовал в политической жизни эмиграции, создатель так называемого Федоровского комитета (Центрального комитета по обеспечению высшего образования русскому юношеству за границей) - организации, оказывавшей действенную помощь русской эмигрантской молодежи, прежде всего студенчеству; стипендиатом Федоровского комитета был, в частности, Я. Цвибак. О М.М. Федорове см.: [17]. 4I ДРЗ. Ф. 4І. Оп. 3. Ед. хр. 467. Л. ІІ-І2. Опускаем часть письма, посвященную эмигрантскому быту. 
Дорогой Иван Сергеевич.

Получил Ваше заказное. Совершенно с Вами согласен в неучастии в «театрально-дипломатическом» акте. Сам не пойду (кстати, я избавлен и от морального давления в форме пригласит<ельного> билета). Согласен с Вашим отказом участвовать и в «контр-чествовании», где крадучись, тайком будут протаскивать «в праведники». Федоров этого не поймет. Я понимаю и одобряю. Но сам вынужден участвовать, ибо мой более грубый общественно-политический панцирь для того и надет, чтобы быть неуязвимым от таких стрел и царапин. Праведником он - юбиляр - не станет, но ранен и омрачен будет. Этого требует vox populi от нас, особенно в виду лиго-национного духа Елисейского торжества. Все будет естественно (есть напор, есть невысказанное у обывателя, да и не только у обывателя), хоть, быть может, и несладко юбиляру.

Втайне надеемся, что это внушит ему, по меньшей мере, долю осторожности и оглядки в русскую сторону.

Чествование И.А. Бунина по случаю присуждения ему Нобелевской премии по литературе состоялось 26 ноября в Театре Елисейских полей. Как и предполагалось, вступительное слово сказал В.А. Маклаков, о Бунине-писателе говорил Б.К. Зайцев, главными французскими ораторами стали профессор Оман и писатели братья Таро. Принимая поздравления, Бунин, по свидетельству газеты «Возрождение», отвечал «умно, просто, мило» [8, с. 433]. Н.К. Кульман сообщил о 800 поступивших приветствиях. Так, Этторе Ло Гатто, один из тех европейских славистов, кто принял участие в кампании по выдвижению Ивана Бунина на Нобелевскую премию, прислал телеграмму на имя своего доброго знакомца М.А. Осоргина, который и зачитал ее по-итальянски. Телеграмма сохранилась без даты ${ }^{42}$ :

Сожалею, что не смогу присутствовать лично, прошу представлять меня и Институт Восточной Европы 26 <ноября> в день празднования <присуждения> Нобелевской премии прославленному сыну земли русской Ивану Бунину. 
О главном парижском собрании в честь Бунина в дневнике П.Е. Ковалевского сохранились не самые восторженные заметки. Так, в понедельник, 27/І4 ноября он записывает:

Вчерашнее Бунинское торжество прошло довольно серо. Так как билеты продавались очень дорого, то средние ${ }^{43}$ все остались на руках, балконы были пусты, внизу посадили почетных <гостей>, которым вручили даровые или удешевленные контрамарки, а русская публика была загнана на самый верх. Сам юбиляр <так!> сидел и читал какие-то бумаги. Haumant ${ }^{44}$ говорил, как всегда, хорошо, Tharot - слишком высокопарно. Маклаков и Зайцев тоже могли бы сказать прекрасно, но общая обстановка была многим не по душе. Концерт тоже не подходил ${ }^{45}$. Например, одна певица к случаю исполнила песнь, которая заканчивалась поклоном: ясно, надо было поклониться юбиляру, но она и этого не догадалась сделать. Сегодня в городе говорят, что в театре было "много русских, но всего - три православных Митрополита, гр. Коковцев и еще кто-то”. Доход, видимо, не большой, а удовольствия - никому ${ }^{46}$.

Никто и не вспомнил о такой трогательной задумке, как букетик пармских фиалок лауреату - холодным ноябрьским вечером из ручек русской девочки в балетных туфельках. Отчет о торжестве был набран, однако таким образом, чтобы оставить ниже несколько строк для объявления: «Ида по-французски», - о публикации в еженедельнике «Же сюи парту» («Je suis partout») рассказа Бунина «Ида» в «передающем дух и оттенки подлинника» переводе Б.А. Лазаревского. Но кто из читавших газету помнил, что у бунинской героини «фиалковые глаза»?.. На нескольких страницах рассказа деталь эта повторяется четырежды. Б.К. Зайцев, чья приветственная речь была напечатана в «Возрождении» полностью, проницательно говорил о

\footnotetext{
43 То есть средние по цене - не самые дорогие и не самые дешевые, последние ряды партера, амфитеатр и бельэтаж (балкон).

44 В записи от I7 декабря П.Е. Ковалевский так аттестует своего профессора в Сорбонне: «Навещал моего старого и верного друга Омана» (л. 28).

45 В музыкальном отделении участвовали хор Н.П. Афонского, певицы Е. Турель и М.А. Гонич, пианистка И. Энери (она исполнила пьесы Рахманинова и Глазунова) и певец А.И. Мозжухин. За роялем - Т. Дембо и Карини-Мозжухина.

46 ДРЗ. Ф. 69. Оп. г. Ед. хр. 46. г933 г. Ноябрь-декабрь. Л. 7-8. Газета «Возрождение» иначе описывает общий душевный подъем: «Зал подымается со своих мест и стоя приветствует чествуемого» [I7].
} 
прозе лауреата, пропущенной «сквозь (волшебную) призму поэзии. Все - в некоем мифологическом, очень тонком и легком тумане. Действительность смешивается с воображаемым - и наоборот» 47.

На следующий день после чествования в Театре Елисейских полей (запись от г5/28 ноября) П.Е. Ковалевский передает информацию буквально из первых уст, но свое мнение не разглашает urbi et orbi, а доверяет дневнику:

Маклаков говорил сегодня отцу, что, несмотря на утверждения устроителей «Бунинского торжества», что они действуют в контакте с Комитетом Дня русской культуры и русской общественности, его ни о чем не спрашивали, хотя он - председатель Комитета и представитель эмиграции ${ }^{4}$. Я. Цвибак не только едет в Стокгольм, но получает вознаграждение от Бунина. Какой позор! Неужели он не мог выбрать себе в секретари русского. Взял бы Леонида Зурова, с которым так близок, а то взять с собой мелкого еврея в Стокгольм - просто возмутительно 49 .

Разболевшийся в нетопленой квартире Шмелев послал свое приветственное «слово» Карташеву для прочтения на альтернативном чествовании лауреата, и ответное письмо приходит незамедлительно, написанное без четверти 9 утра:

47 Зайщев Б.К. Бунин (Речь на чествовании писателя 26 ноября) // Возрождение. 1933. 28 ноября. № 3гог. С. 2.

48 В газете «Возрождение» материал «Собрание в Театре Шанз-Элизе» начинался следующим абзацем с известными фигурами умолчания: «Если судить по наплыву публики на воскресное торжество, устроенное по необходимости наспех, можно предполагать, что при иных условиях празднество вышло бы еще более внушительным» (См.: Ч. <Чебышев Н.Н.> Чествование И.А. Бунина. Собрание в Театре Шанз-Элизе // Возрождение. 1933. 28 ноября. № 3Іог. С. 2). И чуть ниже: «Причастных к устройству вечера можно сразу узнать по взволнованным и даже слегка расстроенным лицам».

49 ДРЗ. Ф. 69. Оп. г. Ед. хр. 46. Л. 9. Я.М. Цвибак (известный в русской эмигрантской прессе как А. Седых) честно сослужил Бунину службу пиар-агента, на которую был приглашен, посылая корреспонденции в «Последние новости» и «Сегодня» со всех остановок в пути и ежедневно из Стокгольма. Я. Цвибак прислал, вероятно, и самую последнюю в нобелиаде телеграмму, адресовав ее 9 ноября 1934 г. в Грасс «Maitre Bounine»: «Шлю привет в память о годовщине Нобелевской премии, с наилучшими пожеланиями на будущее вашей семье, с любовью, Цвибак» (РГАЛИ. Ф. 44. ОП. 2. Ед. хр. І37. Л. 5I). 
Дорогой Иван Сергеевич.

Сию минуту получил Ваше заказное. Через І2 минут бегу на лекцию. Посему краток.

Самое главное: разрешите мне в среду же вечером вместе с моею речью передать и Вашу для напечатания в «Возрождении». Это и будет Вашим там началом, как бы хроникерски-механическим (я так тогда и условился с Гукасовым). Кроме того, наши речи возьмет и «Россия и Слав<янство » в описании всего торжества. Черкните мне Ваше разрешение или запрещение срочно, пнё5о или кратчайшей телеграммой: да, нет.

Речь Вашу не дам читать Федорову - убьет! Сам прочитаю, если не найду другого чтеца <...>.

И на этом чествовании 29 ноября ${ }^{5}$ побывал П.Е. Ковалевский. Его настроение немного изменилось в пользу лауреата, и, хотя небольшой осадок остался, в целом этим новым торжеством Ковалевский остался доволен. Стоит, кстати, заметить, что его оценки продиктованы восприятием, с одной стороны, глубоко верующего человека, а с другой - профессионального историка литературы, доктора наук: быть может, в его дневнике впервые письменно прозвучал термин «буниноведение». П.Е. Ковалевский записывает:

Вечером собрание (более интересное и более «правое») в Международном студенческом очаге ${ }^{52}$. По <ошибочно “при”> приглашению собралось до I50 человек. Чествование прошло очень хорошо. Владыка отслужил краткий напутственный молебен и сказал очень хорошо несколько слов. М.М. Федоров прочел речь (великолепно написанную) Шмелева, который по болезни не мог приехать. Слишком много было Струве: Петр Бернгардович сказал, заглазно, не сговорившись, то же самое, и, хотя это было умно и правильно, но обременительно. Лоллий Ив<анович> Львов тоже пересолил и говорил три

50 То есть «пневматичкой», пневматической почтой (la poste pneumatique), действовавшей в Париже с г866 по г984 г.

5 I Л.Ю. Суровова в статье «Писатель и богослов: Письма А.В. Карташева к И.С. Шмелеву» [15, c. 185] это празднование в честь Бунина в Париже, на котором Карташев выступал и общался с лауреатом, датировала невозможным I7 декабря, поскольку к этому моменту Бунин уже находился на обратном пути из Стокгольма, с долгой остановкой в Германии. 52 В Foyer international des étudiants чествование «академика Бунина» было организовано газетой «Россия и славянство», Русским национальным комитетом и Центральным комитетом по обеспечению высшего образования русского юношества за границей. 
раза. К.И. Зайцев прочел интереснейшую лекцию по буниноведению, не подходившую к данному случаю. Хорошо и кратко говорил А.В. Шатков от «Молодежи и студентов». Было два больших но: Бунин пришел с двумя женами, и ненастоящая имела дерзость тоже полезть на эстраду, и к обычной своей гордыне Ив<ан> Ал<ексеевич> прибавил надменность героя53. Последнее, впрочем, было исправлено Карташевым, который в одной из замечательнейших речей, которые мне когда-либо приходилось слышать, как по высоте мысли, так и по красоте формы, поставил все точки над і и заповедал Бунину ехать не как писателю, а как «вестнику и представителю» увенчанной $\underline{\text { B }}$ его лице великой русской литературы и не превозноситься лично за себя. В общем, вечер был первоклассный.

Проводив Бунина 3 декабря в Стокгольм, русский Париж выдохнул. Напряжение было неимоверное не только для лауреата, пресса и читатели слегка подустали от приветственных слов, здравиц, речей и бесконечных публикаций о Бунине и тиражирования его портретов. Та «великолепно написанная» речь Шмелева, которая пришлась по душе Петру Ковалевскому, не нашла места на страницах газеты «Возрождение». Накануне отъезда лауреата за премией, 2 декабря А.В. Карташев отослал И.С. Шмелеву целый эпистолярный «пакет», содержимое которого проливает свет на неумение «правых» (монархистов, православно и национально ориентированной части эмиграции) объединиться вокруг общего дела, в отличие от «левых» (либерально-демократического спектра эмиграции), которые дружным хором поздравляли нобелевского лауреата и славили его на страницах газет, прежде всего в «Последних новостях». А.В. Карташев воссоздает своего рода «оппозиционную» нобелиаду 54 .

53 И в Париже, и в Стокгольме Бунин появился в сопровождении В.Н. Буниной и Г.Н. Кузнецовой. Однако если русская эмиграция была отлично осведомлена о личной жизни мэтра, то в Швеции Галину пришлось выдавать за литературную ученицу и приемную дочь, чем она была чрезвычайно оскорблена и унижена. Л.Ф. Зурову она написала непосредственно в день торжества, недовольная фотографиями, недовольная своим положением: «Выходим мы, однако, ужасно - что-то преступное. Все газеты меня принимают здесь за дочь» (ДРЗ. Ф. 3. Оп. г. Ед. хр. 5О. Л. 29). Между тем «В<ера $>\mathrm{H}<$ иколаевна > похожа на фильмовую актрису» (ДРЗ. Ф. 3. Оп. І. Ед. хр. 5О. Л. 29). Зурову Кузнецова пишет, что ее именуют «m-lle»по-шведски их аттестовали как «fru Bunin» (Веру Николаевну) и «fröken Bunin» (Галину Николаевну).

54 ДРЗ. Ф. 4г. Оп. 3. Ед. хр. 467. Л. І6-2г. 
Само письмо Карташева состоит из двух страниц, первая из которых почти каллиграфическим почерком и, судя по отсутствию помарок, явно переписана с черновика. Антон Владимирович сообщает Ивану Сергеевичу едва ли не по пунктам свои действия: 30 ноября отослал обе приветственные речи - свою и Шмелева - «не почтой, а с посланцем, прямо» Гукасову. I декабря в газете ничего не появилось55, и Карташев «сразу почуял, что и не появится», казнит себя, что не может «отделаться от наивности, что люди ревнуют о национальном интересе, а не о своей лавочке»56. Зато следующая страница, с пометой «доверительно», написана с большим темпераментом и совсем не так прилежно и разборчиво ${ }^{57}$ :

Гукасов, говоря со мной тогда еще, до Елисейского празднования Бунина, жаловался, что Бунина захватили левые, чтобы исказить смысл праздника, и умолял меня прийти и от лица «Возрождения» сказать слово, исправляющее односторонность освещения. А ведь когда я это сказал, но не от «Возр <ождения >», а от «Р< $<$ оссии > и $\mathrm{C}<$ лавянства $>$ », хотя и даю напечатать первому «Возрождению», это отвергается. Следов<ательно>, не национальный интерес, а лавочка... О, людишки!

Они дали «исчерпывающую полноту» при «вполне освещенной теме», и, значит, достаточно Б. Зайцева и Городецкой, значит, вообще у «Возрождения» полнота мыслей, слов, талантов. Тогда, действительно, незачем приглашать, а надо просто гнать всех других как лишних.

$<. .>$ Могли бы и не упоминать, как у Вас написано: Слово на чест <вовании $>$ Бун<ина $>29$ нбря <так! $>$ (не указано где).

у меня - тоже без заглавия. На особом (без пагинации) листке я написал примечание: «Речь, сказ $<$ анная $>$....... устр $<$ оенном $>$ «Росс $<$ ией $>$ и Слав $<$ янством $>$, Русс $<$ ким $>$ нац $<$ иональным $>$ ком $<$ итетом $>$ и др $<$ угими организациями >».

Но я не обязывал их это печатать. Предоставил усмотрению редакции.

Но они топорно, головотяпски решили пожертвовать главным во имя своей идиотской амбиции.

55 Если не считать публикации на с. 2 краткой благодарности И.А. Бунина всем, поздравившим его с Нобелевской премией, а на с. 4 - заметки о собрании в честь лауреата в Софии.

56 ДРЗ. Ф. 4г. Оп. 3. Ед. хр. 467. Л. г7.

57 Там же. Л. І8-г9. 
Их цель - «как бы не доставить удовольствия Лоллию Львову».

Ох, глупости, глупости.

И смешно, и тошно!

Далее (л. 20) Карташев переписывает для Шмелева копию своего письма А.О. Гукасову, написанного в тех же выражениях («снаивничал», «ввел в искушение И.С. Шмелева»), в каких оправдывался перед Шмелевым, и уведомляющего издателя «Возрождения», что «ультра-дипломатическую пневматичку секретаря редакции» он переслал обиженному писателю. Далее следует копия той самой пневматички от 30 ноября (л. 2I), подписанной секретарем редакции С.Г. Долинским. Оригинал был написан на бланке газеты «Возрождение», с указанием имени ее редактора - Ю.Ф. Семенова, только 9 ноября отбившего нобелевскому лауреату телеграмму следующего содержания «"Возрождение” шлет вам свои искренние поздравления и радуется со всеми русскими людьми знаку уважения, вполне заслуженному» ${ }^{58}$. За три недели настроение в редакции существенно изменилось:

К сожалению, - и вы, конечно, это поймете, - для газетного издания наступил какой-то «психологический предел» для помещения сообщений о встречах и чествованиях нашего нобелевского лауреата И.А. Бунина.

Общая национальная оценка этого радостного события нами была уже своевременно дана с исчерпывающей полнотой. И Юлий Федорович $<$ Семенов $>$, и Абрам Осипович $<$ Гукасов $>$ находят затруднительным для газеты освещать еще и собрание, устроенное газетой «Россия и славянство». В будущем мы предполагаем лишь давать репортаж о поездке И.А. Бунина в Стокгольм.

Поэтому, к величайшему нашему сожалению, мы не видим - каким образом вернуться к уже вполне освещенной теме, некоторая «психологическая» срочность которой для газеты, так сказать, уже истекла.

Вот если бы Иван Сергеевич прислал нам одно из своих беллетристических произведений, мы, разумеется, с радостью бы его тотчас же опубликовали. 
И пусть Иван Сергеевич не поймет нас превратно. Мы ждем его все...

Этот чрезвычайно учтивый и, по сути, скорее благоприятный для Шмелева ответ редакции «Возрождения» (про Бунина больше не надо, читатель пресыщен, но сочинения Шмелева на страницах газеты всегда желанны), успокоил Ивана Сергеевича. Дав ему остыть, А.В. Карташев завершает тему нобелевских чествований Бунина в письме от 5 декабря59:

<...> С М.М. Фед<оровым> я уже по телефону дважды поругался изза его освирепленного ража - во что бы то ни стало читать Ваше «слово»: «Никому не позволю читать! Я сам прочитаю отличным образом, как бы сам он (т. е. Вы!) прочитал!!» - кричал он мне в телефон. Ну, и начал с Вашего «соболезнования», хотел поправиться, но так и не сумел, забормотал что-то...

Читая, затем, Вас громко, «с выражением» ${ }^{60}$, старался, но публика, конечно, подсознательно переживала нелегкую работу расслушивания оригинала сквозь усердное «поновление». Все-таки расслышала ${ }^{61}$. Из парижской

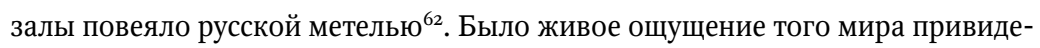
ний, в котором живем мы в отличие от европейцев.

59 Приводим с небольшими купюрами, опуская обсуждение сугубо бытовых вопросов. Буквально в тот же день и час, тоже вечером во вторник, Г.Н. Кузнецова пишет Л.Ф. Зурову на фирменной писчей бумаге с парома Треллеборг-Засниц, на котором - но пока в другую сторону, из Германии в Швецию, - плывет нобелевский лауреат: «5 декабря. Пишу Вам на пароме, в баре. В.Н. дает интервью шведу за одним из столов, а И.А. выбирает сигареты. Скоро 5 ч<асов>, уже темно» (ДРЗ. Ф. 3. Оп. І. Ед. хр. 5О. Л. 27).

60 В тексте «Слова», отложившемся в архиве писателя, проставлены необходимые интонационные маркеры - отточия, восклицательные знаки - и даны пояснения для чтеца: «пауза» (многократно), «Долгая пауза», «крылатая пауза», «другой тон» и под. (ДРЗ. Ф. 4І. Оп. 3. Ед. хр. 89. Л. г, 3, 4).

6I Помимо троекратного «слава» в финале речи - И.А. Бунину, великой русской литературе и «всему народу православному», - Иван Сергеевич Шмелев на все лады, очень убедительно и задушевно повторяет одну мысль: «Через нашу литературу, рожденную Россией, через Россией рожденного Бунина, признается миром сама Россия, запечатленная в “письменах” (См.: Шмелев И.С. Слово на чествовании И.А. Бунина // Россия и славянство. 1933. I дек. № 227. С. 2). Шмелев начинает свою речь с цитирования одного из самых известных стихотворений Бунина: «Молчат гробницы, мумии и кости, - // Лишь слову жизнь дана: // Из древней тьмы, на мировом погосте, // Звучат лишь Письмена». И, одновременно, вольно или невольно, напоминает о другом произведении - книге А.М. Ремизова «Россия в письменах» (Берлин, I922).

62 Шмелев цитирует «Бесов» Пушкина. В этом стихотворении нет слова «метель», есть «вьюга», кроме того, снежная непогода изображена иными средствами. Однако Карташев воспользовался более «пушкинским», литературно освященным словом. 
Было еще много докладов - интересных. Заседание вышло содержательное. Целый праздничный сборник статей в честь «юбиляра». С.В. Яблоновский был на официальном торжестве и свидетельствует, что оно было оч<ень> неудачное, пустое и разгильдяйское - все на песенках да на музыке, как бы отлынивание от чего-то ${ }^{63}$. А этим собранием он оч<ень $>$ удовлетворен. Вообще оно на опыте доказало, что узурпаторство левых есть фальсификация голоса эмиграции.

А к моей речи Бунин только в начале отнесся игриво. Как я перешел на «ты», так все и притихло. И Бунин остолбенел. Ему было нелегко. Он не мог не уязвиться. Он мне не без страха кланялся и жал руку. Но сказать после этого уже ни слова публике не решился. Даже обидел многих, что ушел немым ${ }^{64}$. Я видел, что у него остался осадок недовольства и даже у Веры Н<иколаев>ны. Им до сего момента все было комфортабельно. Но зато «все» почуяли удовлетворение, а кто подогадливее - все повторно меня благодарят, даже м<итрополит > Евлогий. Надо - говорят, - это было кому-нибудь сказать. Но вот только недостает печатного эха. Как раз широкая-то публика ничего и не узнает. И в Стокгольм Бунин уехал ничем печатно не связанный. <...>

63 Суждение не справедливое, поскольку и русские ораторы В.А. Маклаков и Б.К. Зайцев, и французские (писатель Э. Оман, писатель Ж. Таро) меньше всего говорили о заслугах Бунина, а рассуждали о величии русской литературы, русского народа, России, о сохранении ее традиций в эмиграции.

64 «Немота», подобная той, о которой пишет А.В. Карташев, овладела Буниным и три с небольшим года спустя, когда вся эмиграция в едином сердечном порыве отмечала мрачный юбилей, поистине национальный день траура - сто лет со дня смерти Пушкина и одновременно - светлый праздник от радостного сознания, что Пушкин был, он «наше все» и, в сущности, в Пушкине едины все русские люди, в России и за рубежом, целостен русский народ и его самосознание. Именно Бунин - первый писатель эмиграции, как бы предстоятель Пушкина перед своими соотечественниками, в «рассеянии сущими», лауреат Нобелевской премии - должен был произнести в 1937 г. какие-то важные, самые главные слова. Их ждали в эмиграции. Их немедленно услышали бы в СССР. Но Бунин оставался «немым», как и на том вечере, о котором пишет Карташев. Отмечая этот поразительный жест метафизической немоты, автор настоящих строк написал: «Но Бунин на пушкинских торжествах как писатель не появился» [Іо, с. I32]. Один из исследователей Бунина решил взять своего «героя» под защиту и перечислил в ответ все мероприятия, которые нобелевский лауреат посетил [I, c. 396]. Но мы также перечислили все эти мероприятия - присутствовавший на них физически, Бунин везде оставался «немым» писателем, т. е. не смог прожечь глаголом сердца людей (как, например, удалось ему в 1924 г. речью «Миссия русской эмиграции»). Нам радостно найти союзника в А.В. Карташеве, человеке мудром и тонком, но столь же печально сознавать, что публикаторы наследия великого русского писателя Бунина так порой нечутки к оттенкам слов и их контекстным значениям. 
«Слово на чествовании И.А. Бунина» появилось не в «Возрождении» ${ }^{65}$, а в газете «Россия и славянство» ${ }^{66}$. Печатный резонанс оказался действительно недостаточно сильным, однако пламенная речь Шмелева не исчезла из памяти свидетелей тех дней и их потомков, но обрела иного... автора. Михаил Михайлович Федоров ${ }^{67}$ не напрасно бился истово за право произнести шмелевское приветствие. Его внук Мишель Федоров (Fedoroff) так воспроизводит этот эпизод из бунинской нобелиады [I6, с. 20о]:

Михаил Федоров организовал в честь Бунина вечер в зале американского студенческого общежития на бульваре Сен-Мишель, в доме 93. Он произнес с большим чувством речь о том, что благодаря бунинскому таланту зарубежную Россию признали центром русской культуры, что культуру эту нужно хранить, чтобы суметь ее передать России, когда та освободится от советского режима.

С наказом представлять русский эмигрантский национально-духовный «конклав» и делегировало Бунина в Стокгольм собрание, устроенное газетой «Россия и славянство» и Федоровским комитетом, напутствие помнить о своей духовной миссии звучало во всех речах, но прежде всего в «Словах» Шмелева и Карташева. Бунин, однако, заповедям и заветам не внял ${ }^{68}$. Какие ожидания возлагала эмиграция на нобелевского лауреата,

65 Впрочем, в «Возрождении» в этот день имя Бунина все же мелькнуло. На с. 6 в «Хронике» появилось объявление: «Лекция проф. Н.К. Кульмана о Бунине - назначенная на сегодня в Сорбонне - по не зависящим от лектора обстоятельствам откладывается». См.: Шмелев И.С. Слово на чествовании И.А. Бунина...

66 Шмелев И.С. Слово на чествовании И.А. Бунина. С. 2.

67 Для понимания личности и credo М.М. Федорова в эмиграции стоит привести слова из мемуарного очерка его внука: «Когда я читаю страстные призывы деда ко всем русским эмигрантам создать единый фронт для продолжения борьбы с советским режимом, это пробирает до слез. В отличие от многих эмигрантов, он до конца своей жизни проявлял абсолютную непримиримость к советскому режиму. Он жил с мыслью, что этот режим, который он считал преступным, долго не простоит и что оказавшаяся в эмиграции русская элита вернется и будет строить новую, свободную Россию и в этом ей помогут студенты, которым он сумел обеспечить образование. И тогда я понял, что это мой долг - рассказать об удивительной жизни патриота и демократа, жившего в трагический период истории, и передать те ценности, борьбе за которые он посвятил свою жизнь» [15, с. Іо].

68 Впрочем, разногласия в «стиле» порой приводили к qui pro quo смыслов, в которых и сейчас нелегко разобраться. Так, В.Н. Бунина упрекала мужа, что в Париже он неразборчиво дает интервью, усиленно «лоббируя» необходимость собственного - «интеллектуальной женщины» - присутствия на торжествах в Стокгольме. Ее также раздражает Я. Цвибак, 
видно из еще одной записи в дневнике П.Е. Ковалевского, в которой его автор обнаруживает резкое недовольство стокгольмской речью Бунина, которой тот по праву гордился. Бунин выражал благодарность принявшей его Франции, говорил о свободе творчества, а определенной части эмиграции чудилось в его словах забвение России, о которой Бунин только и писал и литературе которой принадлежал без остатка:

Бунин окончательно опозорил себя речью в Стокгольме, которая напечатана в вечерних газетах ${ }^{69}$. Ни одного слова о русской литературе, которой он обязан премией. Гордыня его зашла, право, очень далеко. Он «взял на себя духовную миссию» говорить о русской литературе и, вместо этого, позорно выставил самого себя и раскланялся только перед Швецией и Францией ${ }^{70}$.

Сейчас стокгольмская речь Бунина представляется как раз победой. По возвращении И.А. Бунина из Стокгольма И.С. Шмелев и А.В. Карташев получили от нобелевского лауреата чеки - на 3 и 2 тысячи франков соответственно - и с признательностью приняли этот дар [3, с. 688-690].

\section{Утомленное солнце}

Из всех слов, произнесенных и написанных Буниным в ноябре-декабре І933 г., самой искренней выглядит его приписка на письме Галины Кузнецовой Леониду Зурову из Стокгольма го декабря ${ }^{\text {I }}$. К суматохе нобелевских торжеств прибавился и семейный праздник - день рождения Кузнецовой. Письмо подробное и не очень веселое, женский взгляд на бегу улавливает мелочи скандинавского, столь отличного от французского стиля жизни: «Здесь множество очень милых маленьких вещей, напр<имер>, но влияние его на лауреата она интерпретирует неожиданным образом: «А что несут твои новые “любимцы” - какая порой бестактность <..>. Мы прочли внимательно, например, запись Цвибака, и только две твои фразы, остальное а̀-ла-Шмелев!..» [3, с. 666].

69 В газете «Последние новости» II декабря г933 г. (№ 4646) эта речь была напечатана внутри большой подборки (А. Седых подписывал только авторские корреспонденции, те материалы, где шли отчеты о мероприятиях и перепечатывались чужие тексты, публиковались без подписи): «Торжества в Стокгольме. Вручение нобелевских премий. Заседание шведской академии. Банкет в честь лауреатов. Речь И.А. Бунина».

70 ДРЗ. Ф. 69. Оп. г. Ед. хр. 46. Л. 24. Запись от 28 ноября / гі декабря г933 г. Подчеркнуто цитируемым автором.

7 І ДРЗ. Ф. 3. Зуров Леонид Федорович. Оп. г. Ед. хр. 5о. Л. 29-30. Далее цитируется это письмо, автограф И.А. Бунина на л. 30. 
спичечные коробки <...>. Есть чудные несессеры, хрустальные вещи и знаменитые шведские перчатки». Письмо начинается с упоминания подарков: внимательный «Яша» (Цвибак) подарил «пару отличных шведских перчаток (кремовых)», а Вера Николаевна - «очаровательную белую бисерную сумочку» («для вечерних платьев», уточнит сама дарительница ниже). И только виновник торжества (нобелевский лауреат) не подарил виновнице торжества (имениннице) ничего: «И.А. говорит, что пытался купить мне подарок, но все заперто». Пожелав Зурову «будьте веселы», Галина Николаевна оставила полстраницы для приписок. Вера Николаевна лучится счастьем в нескольких строках, зимний день кажется ей «чудесным, летним», она счастлива тем, что «семь обедов, нужны перемены», и потому заказаны еще платья (в утешение Галине - у нее «чудесный цвет»). Крупно, коряво, царапая пером бумагу, ставит свой автограф Бунин - и это буквально вопль души: «Целую. Замучен».

Треть века спустя, весной г965 г. Г.Н. Кузнецова поздравляла Л.Ф. Зурова с Пасхой, передавала троекратные лобызания от себя и от М.А. Степун и делилась душевными муками, связанными с публикацией ею «Грасского дневника». Уже не было в живых ни Ивана Алексеевича, ни Веры Николаевны, а главным действующим лицом бунинской биографии стал А.К. Бабореко (его Кузнецова именует в письме Бобореко), приступивший к трепетному, тщательному и настойчивому восстановлению по крупицам хроники бунинской жизни, личной и творческой. В послании от 22 апреля «Галя» сообщает «Лёне», как трудно ей дался для печати «последний кусок» автобиографической книги:

Вы правы, грустного было много. <...> Вы лучше всех знаете, что много-много было тяжелого. Но зачем это печатать? Яша Цвибак, отдавая свой архив и письма И.А. в Йельский университет, вычеркнул все порочащее кого-нибудь и написал Бабореко об этом, говоря, что И.А. писал часто сгоряча, а через полчаса посылал другое письмо, в котором все опровергал. У меня много писем таких, которые нельзя совершенно опубликовывать. Я вообще буду держаться некоей уравновешивающей линии. Думаю, что это благороднее во всех смыслах ${ }^{72}$.

72 ДРЗ. Ф. 3. Зуров Леонид Федорович. Оп. І. Ед. хр. 50. Л. 74 а. Подчеркнуто Г.Н. Кузнецовой. 
Последние непосредственные участники «нобелевского действа» завершали земные дела, печатали воспоминания, готовили на хранение архивы. Их жизни состоялись и продлились в памяти потомков благодаря близости к Бунину, существованию рядом с ним, растворению в нем. Места хватало и огорчениям, и фарсу. И был праздник - общий для всей эмиграции и семейный для бунинского круга: присуждение Нобелевской премии. Незабываемый. Процитированная пасхальная «открытка», проливающая свет и на прошлое, и на настоящее, где литература и жизнь оказались неразрывно слиты, написана на сложенном почтовом листочке с изображением хранящегося в Альбертине (Вена) «Букета фиалок» Альбрехта Дюрера.

Считаем своим приятным долгом выразить искреннюю благодарность сотрудникам Дома русского зарубежья Светлане Романовой, Дарье Акуловой и Наталье Ликвинцевой за оказанную поддержку при работе над этой статьей. 


\section{Список литературы}

I Бакунцев А.В. «Знаем, что на подъем вы не очень легки...». Письма П.Н. Милюкова к И.А. Бунину, І92I-I937 гг. / публ., подгот. текста, вступ. ст. и коммент. А.В. Бакунцева // Ежегодник Дома русского зарубежья им. А. Солженицына 20I6. М.: Дом русского зарубежья им. А. Солженицына, 2ог6. С. 376-405. Иван Бунин: в 2 кн. / ред. В.Р. Щербина и др. // Литературное наследство. М.: Наука, І973. Т. 84. Кн. г. 696 с. Т. 84. Кн. 2. 55I с. И.А. Бунин. Новые материалы и исследования // Литературное наследство. М.: ИМЛИ РАН, 2ОІ9. Т. ІІо. Кн. І / ред.-сост. О.А. Коростелев, С.Н. Морозов. II84 c.

4 Боровская А.А. Русская эмиграция в Швеции: проблемы взаимоотношений диаспоры, государства и общества (I9I8-1940): дис. ... канд. ист. наук. СПб., 2017. 4I6 c. URL: https://disser.spbu.ru/files/phd_spsu/borovskaya_diss.pdf (дата обращения: 13.12.2019).

5 Двинятина Т.M. Нобелевский год И.А. Бунина. По материалам дневников и семейной переписки // Литературный факт. 20I7. № 4. С. І43-г6г.

6 П.Е. Ковалевский. Дневники (январь-февраль г924) / публ., вступ. ст. и коммент. Н.В. Ликвинцевой // Ежегодник Дома русского зарубежья им. А. Солженицына 2019. М.: Дом русского зарубежья им. А. Солженицына, 2019. С. 85-87. Марченко T.B. Неизвестные страницы бунинской Нобелианы (по материалам архива Шведской академии) // Изв. РАН. Сер. лит. и яз. І997. № 6. С. 23-35. Марченко Т.В. Русские писатели и Нобелевская премия (I9OI-I955). Köln; München: Böhlau Verlag, 2007. 626 S. (Bausteine zur slavischen Philologie und Kulturgeschichte; Bd. 55). $<$ Марченко Т.В. Введение> Французская (франкоязычная) критика // Классик без ретуши: Литературный мир о творчестве И.А. Бунина: Критические отзывы, эссе, пародии (І890-е-г950-е гг.): Антология / под общ. ред. Н.Г. Мельникова; сост., подгот. текста, коммент. Н.Г. Мельникова, Т.В. Марченко. М.: Русский путь, 20IO. $926 \mathrm{c}$. Марченко Т.В. «...Мало бунинской атмосферы, нужна и блоковская»: Поэма А.А. Блока «Двенадцать» в художественном сознании И.А. Бунина // Ежегодник Дома русского зарубежья им. А. Солженицына 20II. М.: Дом русского зарубежья им. А. Солженицына, 201г. С. 45-73. Марченко Т.В. «Венок лауреата ему точно впору»: французская пресса о Нобелевской премии Бунина // Материалы Международной научной конференции «От Бунина до Пастернака: русская литература в зарубежном восприятии (к юбилеям присуждения Нобелевской премии русским писателям)» / сост. и ред.

T.В. Марченко. М.: Русский путь, 20II. С. I3I-I5I. Марченко T.B. Русская литература в зеркале Нобелевской премии. М.: Азбуковник, 2017. 672 с. 
I3 Морозов С.Н. История подготовки Собрания сочинений И.А. Бунина в издательстве «Петрополис» (по материалам переписки) // Литературный факт. 20I7. № 5. C. 248-265.

I4 Осипов Ю.С. Академия наук в истории Российского государства. М.: Наука, І999. 204 c. URL: http://www.ras.ru/about/history/ontherise.aspx (дата обращения: I3.12.2019).

I5 Суровова Л.Ю. Писатель и богослов: Письма А.В. Карташева к И.С. Шмелеву // Поэзия русской жизни в творчестве И.С. Шмелева. Шмелевские чтения 2007 и 2009 гг. Материалы Международных научных конференций. М.: ИМЛИ РАН, 20II. C. I79-I9O.

I6 Федоров М. Между короной и наковальней. Жизнь и судьба царского министра М.М. Федорова. І858-г949 / пер. с франц. М.: Русский путь, 2019. 234 с.

I7 Heywood A.J. Catalogue of the I.A. Bunin, V.N. Bunina, L.F. Zurov and E.M. Lopatina Collections. Leeds: Leeds University Press, 20II. 393 p. 


\section{References}

I Bakuntsev A.V. “Znaem, chto na pod”em vy ne ochen' legki...”. Pis'ma P.N. Miliukova k I.A. Buninu, I92I-I937 gg. [“We know that you are not very easy to rise ...”. Letters from P.N. Milyukov to I.A. Bunin, I92I-I937], ed. by A.V. Bakuntsev. In: Ezhegodnik Doma russkogo zarubezh'ia im. A. Solzhenitsyna 20I6 [Yearbook of the A. Solzhenitsyn House of Russia Abroad 20r6]. Moscow, A. Solzhenitsyn House of Russia Abroad Publ., 20I6, pp. 376-405. (In Russ.). Ivan Bunin: v 2 kn. [Ivan Bunin: in 2 vols.] ed. by. V.R. Shcherbina etc. In: Literaturnoe nasledstvo [Literary heritage]. Moscow, Nauka Publ., I973, vol. 84, books I-2, 1973. (In Russ.).

3 I.A. Bunin. Novye materialy i issledovaniia [I.A. Bunin. New materials and studies]. In: Literaturnoe nasledstvo [Literary heritage]. Moscow, IWL RAS Publ., 20I9, vol. IIo, book I, ed. by O.A. Korostelev, S.N. Morozov. II84 p. (In Russ.). Borovskaia A.A. Russkaia emigratsiia v Shvetsii: problemy vzaimootnoshenii diaspory, gosudarstva i obshchestva (I918-1940) [Russian emigration in Sweden: problems of relations between the diaspora, state and society (I9I8-I940): PhD Dissertation]. St. Peterburg, 20I7. 4I6 p. Available at: https://disser.spbu.ru/files/phd_spsu/ borovskaya_diss.pdf (Accessed I3 December 20I9). (In Russ.). Dviniatina T.M. Nobelevskii god I.A. Bunina. Po materialam dnevnikov i semeinoi perepiski [Ivan Bunin's Nobel Year as reflected in diaries and family correspondence]. Literaturnyj fakt, 20I7, no 4, p. I43-I6I. (In Russ.). P.E. Kovalevskii. Dnevniki (ianvar'-fevral' I924) [P.E. Kovalevskii. Diaries (January February 1924)], ed. by N.V. Likvintseva. In: Ezhegodnik Doma russkogo zarubezh'ja im. A. Solzhenitsyna 2019 [Yearbook of the A. Solzhenitsyn House of Russia Abroad 2019]. Moscow, A. Solzhenitsyn House of Russia Abroad Publ., 20I9, pp. 85-87. (In Russ.). Marchenko T.V. Neizvestnye stranitsy buninskoi Nobeliany (po materialam arkhiva Shvedskoi akademii) [Unknown pages of the Bunin Nobeliad (based on the materials from the Swedish Academy archive]. Izvestiia Rossiiskoi akademii nauk, Seriia literatury $i$ iazyka, I997, no 6, pp. 23-35. (In Russ.).

8 Marchenko T.V. Russkie pisateli i Nobelevskaia premiia (I90I-I955) [Russian writers, and the Nobel Prize (I9OI-I955)]. Köln; München; Wien, Böhlau Verlag, 2007. 626 S. (Bausteine zur slavischen Philologie und Kulturgeschichte; Bd. 55). (In Russ.). $<$ Marchenko T.V.> Frantsuzskaia (frankoiazychnaia) Kritika [Frankfurt (Frenchspeaking) criticism]. In: Klassik bez retushi: Literaturnyi mir o tvorchestve I.A. Bunina: Kriticheskie otzyvy, esse, parodii (I890-e-1950-e gg.): Antologiia [French (Francophone) criticism. In: A classic as he is. Literary world on Ivan Bunin: Critical reviews, essays, parodies (I890s - I950s): Anthology], ed. by N.G. Mel'nikov, T.V. Marchenko. Moscow, Russkii put’ Publ., 20Io. 926 p. (In Russ.). Marchenko T.V. “...Malo buninskoi atmosfery, nuzhna i blokovskaia”: Poema A.A. Bloka “Dvenadtsat”” v khudozhestvennom soznanii I.A. Bunina 
["Bunin's atmosphere is not enough; we need Blok's atmosphere..” The Poem Twelve in Bunin's reception]. In: Ezhegozdnik Doma russkogo zarubezh'ia im. A. Solzhenitsyna $20 I I$ [Yearbook of the A. Solzhenitsyn House of Russia Abroad 20II]. Moscow, A. Solzhenitsyn House of Russia Abroad Publ., 20II, pp. 45-73. (In Russ.). Marchenko T.V. "Venok laureata emu tochno vporu”: frantsuzskaia pressa o Nobelevskoi premii Bunina [The laureate's wreath is just right for him: French press about the Bunin Nobel Prize]. In: Materialy Mezhdunarodnoi nauchnoi konferentsii "Ot Bunina do Pasternaka: russkaia literatura v zarubezhnom vospriiatii (k iubileiam prisuzhdeniia Nobelevskoi premii russkim pisateliam)" [Proceedings of the International Conference From Bunin to Pasternak: Russian Literature in the foreign reception (on the anniversaries of the Nobel Prize Award to Russian authors)], ed. by T.V. Marchenko. Moscow, Russkii put’ Publ., 20II, pp. I3I-I5I. (In Russ.). Marchenko T.V. Russkaia literatura v zerkale Nobelevskoi premii [Russian Literature in the mirror of the Nobel Prize]. Moscow, Azbukovnik Publ., 20I7. 672 p. (In Russ.).

I3 Osipov Ju.S. Akademiia naukv istorii Rossiiskogo gosudarstva [Academy of Sciences in the history of the Russian State]. Moscow, Nauka Publ., I999, Available at: http:// www.ras.ru/about/history/ontherise.aspx (Accessed I3 December 20I9). (In Russ.). Morozov S.N. Istoriia podgotovki Sobraniia sochinenii I.A. Bunina v izdatel'stve "Petropolis" (po materialam perepiski) [The history of the Bunin Complete Works at the publishing house Petropolis (based on the correspondence)]. Literaturnyi fakt, 20I7, no 5, pp. 248-265. (In Russ.).

I5 Surovova L.Iu. Pisatel' i bogoslov: Pis'ma A.V. Kartasheva k I.S. Shmelevu [The writer and the theologian: Letters of A.V. Kartashev to I.S. Shmelev]. In: Poeziia russkoi zhizni v tvorchestve I.S. Shmeleva. Shmelevskie chteniia 2007 i $2009 \mathrm{gg}$. Materialy Mezhdunarodnykh nauchnykh konferentsii [Poetry of Russian life in the works of I.S. Shmelev, Shmelev's Readings of 2007 and 2009, Proceedings of the international conferences]. Moscow, IWL RAS Publ., 20II, pp. I79-190. (In Russ.). M.M. Fedorova. I858-1949 [Between the crown and the anvil. Life and fate of the tsarist minister M.M. Fedorov. I858-I949]. Moscow, Russkii put' Publ., 20I9. 234 p. (In Russ.).

I7 Heywood A.J. Catalogue of the I.A. Bunin, V.N. Bunina, L.F. Zurov and E.M. Lopatina Collections. Leeds, Leeds University Press, 20II. 393 p. (In English) 